\title{
THE RECOGNITION OF ISLAM IN THE HUNGARIAN \\ LAW OF 1916 (XVII): DOCUMENTS FROM THE VATICAN ARCHIVES ${ }^{1}$
}

\author{
ORSOLYA VARSÁNYI \\ Pázmány Péter Catholic University \\ varsanyi.orsolya@btk.ppke.hu
}

\begin{abstract}
This article aims to reconstruct the reception of Act XVII adopted by the Hungarian Parliament in 1916, which brought about the legal recognition of Islam, from the stance of the Holy See of Rome. The research is based on archival material preserved at the Vatican Archives, namely letters exchanged between the Nunziature of Vienna and the Holy See, which are published and translated here. The presentation of so far unpublished material provides an opportunity to follow the growing understanding of the contents and background of this law; the key points of interest of the Catholic Church in this matter are identified; while lexical references seek to shed light on the perceptions of Islam.
\end{abstract}

Keywords: Hungarian Islam Law 1916, Catholic Church, Perceptions of Islam, Religious Pluralism

\section{Introduction}

In 2016, intense scholarly activity commemorated the official legal recognition of Islam in Hungary, on the centenary of the so-called 1916 Islam law. Conferences were organized ${ }^{2}$ on the history and the significance of the law from a variety of approaches; and a great proportion of the proceedings was published. Some studies elaborated on the perception of and attitudes to Islam, especially general trends, in the beginning of the $20^{\text {th }}$ century in Hungary, but, to the best of my knowledge, the reactions of the Catholic Church to the emergence of the proposition and the actual proclamation have not been presented in detail so far. (E.g. Köbel - Tóth 2017)

After introducing briefly the context in which the bill was prepared and passed, this article aims to reconstruct attitudes towards and anxieties concerning the law, based on archival material preserved at the Vatican Archives, namely through letters exchanged between the Nunziature of Vienna and the Holy See, which are published here in a transcribed and translated form. ${ }^{3}$ I consulted the following fonds: 


\section{- Archivio della Nunziatura a Vienna - Cancelleria e Segreteria}

The Archivio della Nunziatura a Vienna makes part of the Archives of the Pontificial Representatives (Archivi delle Rappresentanze Pontificie); the fond comprises reports written by the Nuncios of Vienna to the Secretary of the State, and the responses. The material is usually organized in units according to the Nuncio whose correspondence it contains. It is then further divided thematically. Occasionally the thematic principle is stronger, and we can find the correspondence of two Nuncios in one thematic unit.

Arch. Nunz. Vienna 766, fasc. 3: Box 766, i.e. Scapinelli Rafaele, nunzio. Corrispondenza con diversi riguardante le diocesi di Ungheria (1912-16) contains the correspondence of the Apostolic Nuncio Raffaele Scapinelli concerning Hungarian ecclesiastical matters. Fascicle 3, i.e. Legge sul culto musulmano in Ungheria e Croazia (e in Austria) (ff. 38-67 (30.11.1915 - 26.5.1916)) comprises the documents related to the legal recognition of Islam.

Arch. Nunz. Vienna 787, fasc. 3: Box 787, i.e. Valfré di Bonzo Teodoro, nunzio: Corrispondenza con diversi riguardante le dispense matrimoniali, per disparitá di culto e per mista religione (1916-19) contains the correspondence of the Apostolic Nuncio Teodoro Valfré di Bonzo. Fascicle 3, i.e. Disparitá di culto (ff. 179-523. (1916-19)) includes documents on the issues of religious multiplicity.

Arch. Nunz. Vienna 806, fasc. 6: Box 806, i.e. Valfré di Bonzo Teodoro, nunzio: Corrispondenza con diversi riguardante questioni religiose, questioni sociali e associazioni cattoliche makes part of the same fond. Its Fascicle 6, i.e. Questioni religiose e sociali. Culto mussulmano nell'Austria-Ungheria (ff. 420428 (1917 3.8-12. 9.)) is a collection of documents on the legal recognition of Islam.

\section{- Segreteria di Stato, Parte moderna (1816-22; 1846-1935)}

The fond contains the letters received by the Secretariat and the responses sent. It is mostly organized chronologically, but thematic approaches are also considered. The Fascicles are divided thematically. Rubrica 247 always designates Nunziatura di Vienna, i.e. the Austrian-Hungarian ecclesiastical affairs.

Segr. Stato, anno 1916, rubr. 247, fasc. 1 - In this fond, I found relevant material for the legal recognition in the material of the year 1916.

\section{- Fondo Affari Ecclesiastici Straordinari}

The Fondo Affari Ecclesiastici Straordinari can be found in the Historical Archive (Archivio Storico. Segreteria di Stato, Sezione per i Rapporti con gli stati). The Sacra Congregazione degli Affari Ecclesiastici Straordinari was started by Pius VII, and this fond conserves the documents of the work of the Congregation that had the aim of stabilizing the relationship between the Church and the states. 
The material is divided according to geographical regions, and then further organized chronologically and thematically. I found relevant material in the following section: Periodo iii. Pio X Benedetto XV (1903-1922), and in the following fascicles.

Austria Ungheria, anno 1916, pos. 1074-1080, fasc. 466

Austria Ungheria, anno 1914-1917, pos. 1204-1206, fasc. 494.

In the following, key points and recurring ideas of the relevant documents will be identified, and where pertinent, commented upon.

\section{Context}

In 1855, the Monarchy signed a Concordat with the Holy See which accorded to the Catholic Church the status of state church. In 1859, an Imperial Patent equalized the legal status of Evangelical churches with that of the Catholic Church, and after the Austro-Prussian war of 1866, King Franz Joseph, having to unify the Monarchy, deprived the Catholic Church of its status of state religion, notably by the Law of 1868, which proclaimed the equality of all religions in Hungary. (Staničić 2014:226-228.) Thus, in the second half of the age of Dualism, in Hungary, the system of the State Church was terminated, however, the institutions of state and church were not separated. The history of modern Hungarian state/civilian/ecclesiastical law started with the church policy acts of 1894-95. Among these, Article XLIII of 1895 was an intermediary solution, working out the system of a three-phase coordination of denominations: cases that concerned more than one party were synchronized on the level of execution; and canon law divided churches and denominations into three categories. The 'accepted/ established denominations' ("bevett felekezetek") or religiones receptae worked closely together with the state, had privileges, and received material, political, legal and moral support from the state. The 'recognised denominations' ("elismert felekezetek") or religions licitae/recognitae had freedom, full civil rights but no privileges, i.e did not receive state support. The tolerated or not recognized religions ("el nem ismert/türt felekezetek") could operate as associations according to the right of association and assembly in force. This system worked well and was put out of force only by article XXXIII of 1947. (Csiziné Schlosser 2010:245-246; Stipta 2017:23)

In the territory of Hungary and in the age of Dualism, the adherents of Islam could freely confess and follow their religion according to article XLIII of 1895 and could openly express and practice it within the limitations of the law. They were not referred to in the legislation concerning the religious education of children, nor were they accorded any defence for their religious rituals, places of 
worship, clergy or religious objects that penal law provided for recognized denominations. Finally, they had no organization acknowledged by the state. As the Committee of Public Instruction of the House of Representatives noted in 1916, in Hungary, adherents of Islam had only the restricted freedom or toleration of their religion. The 1895 article on churches and the freedom of religion discussed the conditions of acquiring the status of legal recognition. Accordingly, a denomination aspiring for recognition needed to submit its doctrines, organizational and operational rules for approval to the Minister of Culture and Education in writing. If these were not found to go counter to the prevailing laws and did not violate public morality, then the only remaining condition for legal acknowledgement was that the denomination should have an operating community in the territory of Hungary. (Hamza 2016:22; Stipta 2017:24-25.)

The Islam issue emerged in discussions over the destiny of Bosnia-Herzegovina during the Congress of Berlin (1878), which decided that it should belong to the Austrian-Hungarian Monarchy. The Austro-Hungarian authorities guaranteed conditions that led to the preservation of the Muslim population and put into practice the regulations concerning the equality of religions laid down in the treaty of Berlin and its accompanying agreements. However, neither the occupation, nor the annexation of 1908 which rendered this relationship even tighter, resulted in any relevant modifications of Hungarian law. Given that Bosnia-Herzegovina did not become a part of the Kingdom of Hungary, it was not necessary. The necessity for state level regulation of Islam arose through a contradiction. In the part of the country that belonged to the Monarchy, the ruler gave a resolution on $17^{\text {th }}$ February 1910 that guaranteed the freedom of Islam. According to $\S 8$ of the provincial municipal regulations made according to the decision of the Head of State, in the annexed territory, Islam was a legally recognized religion, and, what is more, became one of the main denominations which enjoyed political prerogatives. After this point, the followers of Islam in Hungary, as far as their religious rights were concerned, came to be in a discriminated position in comparison to other citizens who belonged to one of the established or recognized denominations. (Bolek 2017:38; Hamza 2016:20; Krešić 2009:366; Lederer 1988:30; Stipta 2017:25-26; Molodikova 2011:224)

This tension was further exacerbated by the fact that two years later in Austria the opposition was levelled between the annexed territories and the Western part of the Monarchy by legally recognizing the Hanafite rite of Islam (cf. the Austrian Act on the Recognition of Islam according to the Hanefi Ritual as a Religious Society) adopted by the Imperial Diet of 1912 , on $15^{\text {th }}$ July, in an imperial law. This Act came into force in the Austrian part of the Monarchy which included Istria and Dalmatia - Croatian territories whose annexation had been confirmed by the Austro-Hungarian Compromise of 1867. Instead of simply acknowledging the new 'Religionsgesellschaft', which met the existing conditions, through 
administrative channels by a decree to be issued by the Minister of Culture, a separate bill was formulated with respect to the specific characteristics of 'Muhammadanism' and its importance in universal history. After formulating the bill, certain reservations were expressed on the Austrian side with the upper house of legislation claiming that the moral and legal teachings of the Quran contained elements that contradicted the principles of Christian European civilization. However, they declared, there was nothing to worry about: if Muslims came under state rule, these provisions would become invalidated. According to the Austrian bill, only those doctrines, institutions and practices were to enjoy state protection that were not contrary to the laws of that state. (Bolek 2017:39-40; Krešić 2009:366; Stipta 2017:26-27.)

The legal recognition of Islam on the part of Hungary was not simply motivated by the state's commitment to religious freedom, or a neigbourly sentiment towards Islam. In justifying the bill, emphasis was laid on the notion of Turkish-Hungarian brotherhood in arms - WWI positioned Turkey and the Austro-Hungarian Monarchy on the same side as allies. Before the war, Turkey and the Monarchy had fought for shared aims, in alliance; after the Conciliation, the problems of the Balkans were of importance for the leaders of Hungarian politics and for public opinion. Hungarian foreign policy did not consider the declining Ottoman Empire as a threat anymore. This place was taken by the Russian Tsar and the small nations that followed the same religion, and whose nationalisms were supported by the Tzar. So, conflicts with the Turkish empire had ended. On the one hand, Turks engaged with Russia, neutralizing the enemy troops to a large extent; on the other hand, Turkish soldiers often participated in the battles of the Monarchy. Thus the law was also meant to serve as a gesture and came to be the centre of attention of Turkish official circles, and the debate of the bill was supervised personally by several members of the Budapest Turkish community. (Hamza 2016:21-22; Stipta 2017:27; Szalai 2010:593-595; Lederer 1988:30, 38)

This was a period when a positive and friendly attitude began to emerge towards the Turkish nation and "Muhammadanism" in Hungary's public opinion and intellectual circles. The ideology known as Romantic Hungarian Nationalism, which focused on the idea known as pan-Turanism at the turn of the century, was among the factors that contributed to the strengthening of relations with Turkey. This Hungaro-Turkic relationship (a supposed blood relation and the idea of the Turkish origin of the Hungarian language) was not only a political Turanism. Although the Finno-Ugric theory eventually came to dominate the official Hungarian scholarly circles, those ethnographical and linguistic theories that proposed the shared origin of the Hungarians and the Turks in Turan have also always had supporters among scholars such as Lajos Ligeti, Zoltán Gombocz or Gyula Németh. Reference was also made to the eventual frequent future relationship with Turks as part of the justification for the law. (Stipta 2017:27-28; Szalai 2010:593-595) 
Directly before the preparation of the bill - after the annexation of Bosnia-Hercegovina - the number of Muslims in Hungary was increasing. In the Monarchy, the number of the Muslims grew by 500-600 thousand (according to the 1910 census, this was the number of Muslims living in Bosnia-Hercegovina). This territorial enlargement in 1908 led to the beginning of the immigration of Muslims into Hungary. In 1910, the census resulted in the evincing of 553 Muslim inhabitants in Hungary, most of whom were Bosnian soldiers serving in the army of the Monarchy and staying in Hungary. ${ }^{4}$ At the beginning of WWI, there were cca. 2000 Muslims in Budapest, some of whom were soldiers, too, but also Turkish craftsmen and Albanese artisans. The isle of Ada Kali that had formally been under Turkish sovereignty was annexed to Hungary in 1913, which increased this number by a further 500 new members. In 1916, there were 4000 Muslims in the whole of Hungary - coming mostly from the Balkans, including a small Turkish group of 300. In spite of the fact that this inflow of migrants was relatively small, discussions emerged about the place of Islam in Hungary, as the Hungarian law was not in fact developed in the context of a multireligious community. In order to find a solution, the Hungarian Parliament adopted Act XVII of 1916 which acknowledged Islam as a "recognized religion". (Bolek 2017:42; Molodikova 2011:224; N. Rózsa 2010:426; Stipta 2017:28-29; Szalai 2010:594-595.)

When enumerating the factors that contributed to positive attitudes towards Muslims, we may take into consideration that the governor of Bosnia-Hercegovina, Béni Kállai, joint Minister of Finance, depended mostly on the Muslim aristocracy in opposition to the Orthodox elite - who sympathised with the Serbs. Parallel to this, certain interest groups in the Hungarian economiy envisioned an encouraging perspective in the development of Hungarian-Bosnian economic relations, and founded the Hungarian-Bosnian-Hercegovinan Economic Centre (Magyar-Bosnyák-Hercegovinai Gazdasági Központ). The leading circles of Bosnian-Hercegovinan Muslims handed in a petition to the Centre that urged the legal settlement of the position of Islam in Hungary. Due to this initiative, the Centre published a proposal, written by Géza Magyary and addressed to the Hungarian government, which urged the legalization of the religion of Islam taking into consideration especially the relations with Bosnia-Herzegovina, rather than the Muslims of Hungary. (Bolek 2017: 38-41; Lederer 1988:34; Szalai 2010:595) $)^{5}$

It was in this atmosphere that in November 1915 the Minister of Culture and Education, Béla Jankovich (1865-1939) submitted a bill, with the consent of the King, concerning the legalization of the "Muhammadan" religion in Hungary. The bill corresponded to the law that had been passed in 1912 in Austria with the scope of legally settling the situation of Islam in Bosnia-Herzegovina, but needed to take into consideration specific Hungarian circumstances - given that the Austrian Constitution did not contain the specific institution of religiones 
receptae, (accepted religions, “bevett vallások"). The law was made public on $30^{\text {th }}$ March 1916, and declared the religion of Islam legally recognized even before any specific community could request this officially. (Szalai 2010:597; Hamza 2016:22)

\section{The preliminaries, the law, and reactions to it in the documents of the Vatican Archives}

Before the sanctioning of the law, a letter dated to $30^{\text {th }}$ November 1915 and written by Raffaele Scapinelli di Leguigno, Apostolic Nuncio to Vienna (1912-15) in Latin, attests to the fact that a mere fifteen days after the Minister of Culture had submitted the bill, the Nuncio was already thoroughly informed about the matter. The letter does not ask for information or clarification, instead, explicitly presents a judgement on what influence such a recognition would have on the situation and interests of the Catholic Church. The letter itself was addressed to the Archbishop of Esztergom (Card. Csernoch Archiep. Strigoniens i.e. János Csernoch), Primate of Hungary. The very fact that the Nuncio wrote to the head of the Hungarian Church demonstrates the gravity he attibuted to the matter.

\footnotetext{
"In the papers news have already appeared that a new law which is [about] to be formulated is proposed to the Hungarian chamber of legislation concerning the legal recognition of the Muhammadan cult. I think that since this bill makes this false sect equal to the true religion in rights and thus infers not a slight injustice, it cannot be approved by Catholics. What is more: there is no necessity for such a law and, form another [point of view], due to the degree of religious tolerance that is alredy thriving in Hungary, adequate provision is made for such societal demands.

Among other considerations, its consequences are to be noted, namely that as soon as the Muhammadan religion is recognized by law, conversion to that religion from the Christian faith also becomes permitted, which would be extremely harmful to the Christian community. In addition to this, any possible conversion of any person from the false Muhammadan religion to Catholicism will be subject to restrictions and impendiments by which, in Hungary, transition from one religion to another is bound in the case of the recognized religions.

Your Eminence will certainly take care that if it is possible, this law should be not proposed or promoted, or, at least, that it should occur with the least harm and offense to the Catholic religion, Christian morals and opinions concerning conversion."
}

As this first letter already indicates, a major concern throughout the correspondence was and continued to be the issue of conversion. On the one hand, 
conversion to Islam as a recognized religion would have been legally possible, while the conversion to Catholicism from such a religion would have been more restricted in comparison to prior circumstances. The law is presented as unjustified and groundless, as if its only possible justification could have been to provide adequately for social needs. This concern can also be noted in the closing lines, where the Primate is invited to seek to obstruct the sanctioning of such a law ( $\mathrm{si}$ possibile fiat, haec lex non proponatur aut admovetur), which would be harmful to Christians.

The use of phraseology is particular, as we can see in the first passage, in the case of the "Muhammadan cult" (cultus mohamedanus). Though there was already awareness of the inappropriacy of this name, ${ }^{7}$ the proper form "Muslim" (musulmanus/a) can rarely be found in the correspondence. The letter also dubs it a "false sect" (falsa secta), which shows the attitude of the church in face of such a challenge. The possible equality of rights is considered to be "not a slight injustice" (iniuria non levis), which implies a concern that the interests of the Church might be wronged. The form is repeated once again in connection with the possible conversions that would be "very harmful to the Christian community" (societate Christiana valde iniuriosum). Falsity and "Muhammadan" are combined in another instance later, where instead of "sect" the "false Muhammadan religion" (falsa religio mohamedana) is mentioned; and in the closing lines, the idea of damage and offense that would threaten the Catholic religion, Christian morals and liberty (cum minori danno et offensione catholicae religionis christianorum morum et libertatis) is expressed.

The second letter - another one written by the Nuncio to the Primate - is still dated prior to the sanction (8/December/1915), thus attesting to the expectations and worries related to the issue.

"I have received the most honored letters of your most venerable Eminency, from which [I learnt] that the Hungarian government cannot be dissuaded from proposing the law on the recognition of the Muhammadan cult. It is regrettable, indeed almost a disgrace, that Christian legislation be "inflicted" based on political motives.

Hope is to be fostered that no [cases of] Christian apostasy should happen, but, on the other hand, care should be taken that the liberty of conversion from Muhammadanism to Catholicism should not be threatened by the new law - neither through bureaucratic difficulties and formalities, nor concerning the prescribed age, etc.

In Austria, the age of 14 years, in Hungary and Croatia that of 18 years is required as a minimum in case of a wish to convert. In Turkey, having reached adolescence is the only requirement for conversion, and according to the "mecelle", ${ }^{8}$ boys between $12-15$ years and girls between 9-15 years are considered as adolescents (baliq). ${ }^{9}$ This way it will be possible - without any injustice towards the Turks - for the 
Hungarian law also to permit free conversion from that age on.

Setting an age for conversion is always an unjust limitation of the freedom that comes from the natural law of embracing the true religion as soon as one should recognize it as such, even at a tender age, but care should be taken that such limitation should be reduced to the minimum. I can also confidentially say to Your Eminency that in the proposition of the new law which is prepared for Bosnia and Herzegovina, according to the aforementioned criteria, the minimum age for conversion is set at 15 years, but for married women conversion is permitted even before this age. So that bureaucratic formalities are simplified.

If anything can be done concerning this for the benefit of [our] religion, Your Eminency will certainly take care of it.

Perhaps this might also be reduced to 14, as in Austria."10

This letter displays the same attitude and and the same concerns; however, more practical considerations and possible solutions may also be discerned, as this document reflects a later state of the matter. Conversion from and to $\mathrm{Ca}-$ tholicism are the most important questions, and the proposals given mostly turn around these issues. There is a surprising awareness concerning some details ( $m e-$ celle, even the term used in it for puberty, etc), which stands in contrast with the general use of terms and (incorrect) names visible in other instances.

The intention of obstructing the sanction of the law is corroborated (novi gubernium hungaricum moveri non posse ad retractandam propositionem legis de receptione mahumedani cultus), but, taking note of its impossibility, the Nuncio moves on to work out solutions. Words like "regrettable" (dolendum) and "disgrace" (dedecus) are used in the evaluation of the situation, while also an interpretation, that of presuming the political motivations in the background (motivis politicis) is expressed.

Turning to the question of conversion, the use of phraseology demonstrates the underlying concern: while conversion from Catholicism to Islam is dubbed "apostasy" (apostasiae christianorum), it is important to secure that the "liberty of conversion from Muhammadanism to Catholicism" not be threatened (libertas conversionis ex mahumetanismo ad catholicam religionem [...] non minuatur). The same bias is expressed when the age of conversion is considered: while no Catholic should be able to leave his/her religion before the age of $14 / 18$, an effort is made to demonstrate that it would not be unjust to set a lower age limit for Muslims for possible conversions to Catholicism.

The choice of the word to refer to the Muslim community in the phrase "it would not be unjust for Turks" (absque iniuria pro Turcis) might, on the one hand, be interpreted as an awareness of the motivation that the Hungarian legal recognition is in a great part a gesture towards the Turkish ally, but, on the other, such ways of expression show vagueness: as if all Muslims (who are also here referred to with the word Muhammadan) were Turkish. 


\section{The Law}

The first document in the correspondence to contain printed material (in German) is Gesetzartikel XVII betreffend die Anerkennung der islamitischen Religion - Legal Article XVII regarding the recognition of the Islamic religion. ${ }^{11}$ This document is the German version of the Law ${ }^{12}$ which was quickly sent by the Nunziature of Vienna to the Segreteria. A similar document, a handwritten version in Italian, may be found with the title: ,Progetto di legge riguardante il riconoscimento della religione islamistica. In the corner, another hand adds the information: fu approvata feb 16, ammendata 24 marzo 1916 Ungheria, i.e. that it was accepted on $16^{\text {th }}$ February and then amended on $24^{\text {th }}$ March. ${ }^{13}$ Finally, we can find a small piece of paper that contains only $\S 4$ in French - which accords with the wording of the previously seen, Italian version. ${ }^{14}$ All three versions were sent by the Nunziatura. The variety of copies and the use of different translations demonstrate the great interest and the seeking for and giving of information on the bill - even in an international framework. We may stop here and introduce the contents of the law on the basis of the Hungarian text.

$\S 1$ The religion of Islam is declared to be a legally recognized religion. ${ }^{15}$

Hungarian legislation supported the recognition, but it needed to be decided whom the regulation was to include. Austria in its 1912 law had taken into consideration only the followers of the Hanafi rite who made up $96 \%$ of the Muslim population of Bosnia-Herzegovina, but the Hungarian law did not limit itself to a single rite. As there was no formally established Islamic denomination in Hungary at the time, a decree could be effectuated only concerning the religion and the securing of the conditions for founding a community. Corresponding decrees were recorded in a separate law also in the partner countries, i.e. the law of $27^{\text {th }}$ April 1916 on the legal recognition of Islam in Croatia-Slavonia. (Köbel 2016:489-99; Stipta 2017:32-33.)

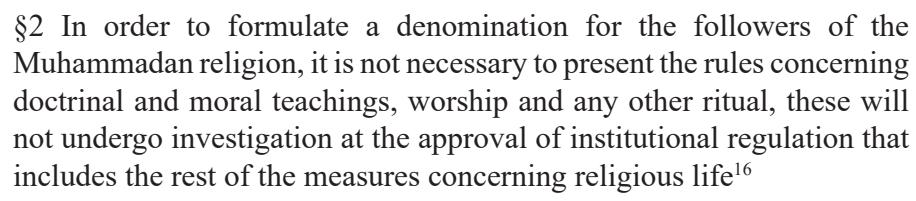

This paragraph provided exemption form the $2^{\text {nd }}$ point of $\S 7$ of $1895 /$ XLIII, i.e. the legal declaration of the recognition of the religion of Islam gave an opportunity for the government to approve the founding of a denomination without examining the dogmas of the religion during the course of approval. (Stipta 2017:33-34) 
$\S 3$ The Hungarian Muhammadan denomination, with the approval of the Minister of Culture and Education, may maintain connection with the legal organization of the followers of the Muhammadan religion in Bosnia and Herzegovina. Individuals whose qualification meets the requirements of such positions may become pastors, parochial magistrates or members of a higher representative body with the approval of the Minister of Culture and Education. Further, pastors may be employed even before the foundation of the first congregation, if they can be provided with a livelihood worthy of their position. ${ }^{17}$

This paragraph gave further concessions for the sake of establishing a local congregation, i.e. to enable the Hungarian organization of the Muslim denomination to remain connected to the legal organisation of the Muslims of Bosnia-Herzegovina. It resolved the contradiction between the institution of the foreign caliphate and $\S 17$ of $1895 /$ XLIII which declared that no individual or authority outside the Hungarian State could be head of a Hungarian congregation, and that no congregation could depend on a foreign authority, denominational association, or individual. (Stipta 2017:34)

\begin{abstract}
$\S 4$ The practice of the religion of Islam, as well as its doctrines, teachings and institutions, within the limits of the laws in force, receive the legal protection due to legally recognized religions. In other respects, such laws are applicable to the Muhammadan denomination as concern legally recognized denominations. Eventual further necessary differences will be established by the regulation of the ministry. ${ }^{18}$
\end{abstract}

The first phrase states that the practice, teachings, and institutions of Islam are entitled to legal protection within the limits of the "laws in force", which in turn guaranteed the protection of the Hungarian laws and moral system. The regulations that generally refer to the legally recognized denominations were also applicable to the Muslim denomination, while any possible differences were to be regulated by decrees of the Ministry. (Stipta 2017:35)

$\S 5$ The law comes into force on the day of its proclamation and is executed by the Minister of Culture and Education, the Minister of the Interior, and the Minister of Justice. ${ }^{19}$

\title{
Perceptions and Reactions
}

Turning back to the archival documents, several letters were exchanged in the matter. As we may see in a handwritten note on top of the letter, dated Zagrab, $9^{\text {th }}$ March 1916, written by archbishop A. Bauer to the Holy See, and besides the letters sent to the Primate of Hungary as seen above, Scapinelli wrote to other 
eminent figures in order to ask for information: "On 6 ${ }^{\text {th }}$ March 1916 the archbishop of Zagreb was sent a letter with the same content as those [sent] to Card. Csernoch on 30th November 1915 and $8^{\text {th }}$ December 1915." ${ }^{20}$ The text of the reply reads as follows:

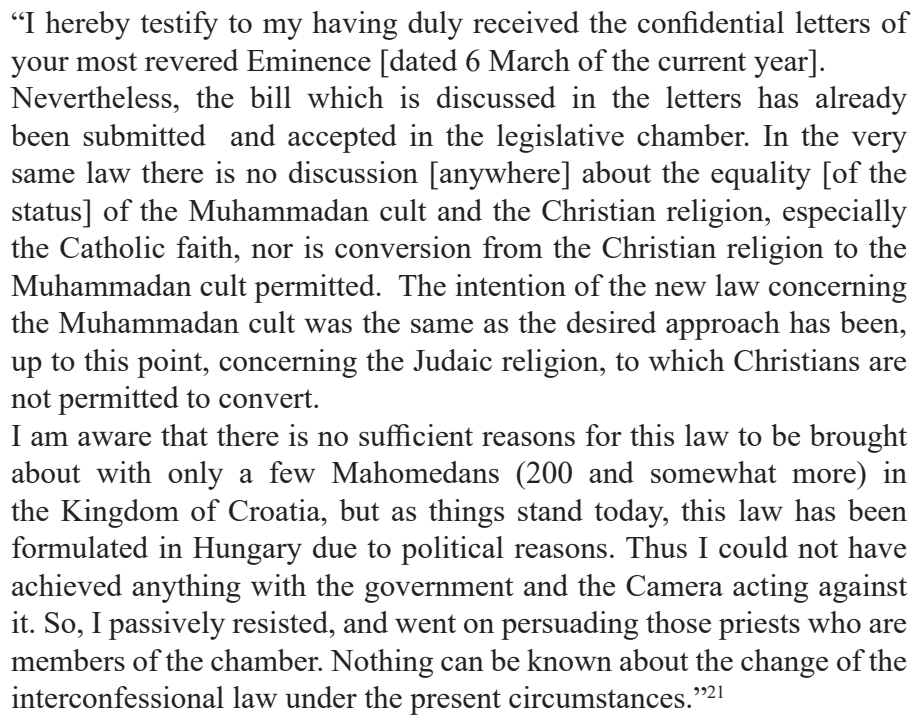

This letter does not refer to the Hungarian law, but, as mentioned above, given that corresponding decrees were also recorded in a separate law in the partner countries, this letter is more a reflection on the subsequent law of $27^{\text {th }}$ April 1916 on the legal recognition of Islam in Croatia-Slavonia. It is nevertheless pertinent to our argument, since the general context and the relfections on the passing of the law are similar, and we could also read the explicit reference to Hungary, where the law was passed "due to political reasons" (lex in Hungaria ob politicas rationes condita nuper sit).

As time passed, more and more became known about the law, e.g., as we may read above, that no efforts were made to render the status of Islam and Catholicism equal. The reference to Judaism makes it clear that equality between two recognized religions/denominations was possible, but that Islam, as well as Judaism, was not going to be an established faith. Leaving Catholicism in order to convert to Islam was not possible, just as it had not been possible before to convert from Catholicism to Judaism (non es fas transire).

Based on the paucity of Muslims, the letter argues that there was no necessity for the formulation of the law, which in this case must have been intended to serve political purposes. It is worth noting the fact that the archbishop found it 
useless to try to protest, as well as his decision to resort to passive resistance and to presuade others to follow suit.

The letter written by Card. Scapinelli, by that time Pro-Nuncio, sent from Wien, which arrived at the See on $17^{\text {th }}$ March 1916, reads as follows:

The Legislative Chambers of Hungary and Croatia have approved the Act on the Recognition of the Muslim cult already in force in BosniaHerzegovina and Austria. Having at the time called the attention of the Cardinal Primate and the Archbishop of Zagrabia to this plan, they have replied to me that it was impossible to prevent the approval which was desired due to political reasons: after all, the practical consequences are almost nil, both because of the small number of Muslims in these countries, and of limited rights related to this recognition. ${ }^{22}$

This account was written in an unbiased tone as far as the events are concerned (approval of the act, entering into force). Scapinelli's contacting the Primate of Hungary and the Archbishop of 'Zagrabia' is recalled, indicating the previous concerns with respect to the formulation of the bill - as it is indicated in the question of the possibility of preventing the approval.

The answer, written by Pietro Gasparri, Cardinal Secretary of State (1914-30) to the Apostolic Pro-Nuncio, Card. Scapinelli in Wien, is a transcription of a ciphertext. The date is $19^{\text {th }}$ March 1916, only three days after the arrival of Card. Scapinelli's letter, and such a quick response attests to the importance of the matter.

\footnotetext{
I have received your ciphertext of the $16^{\text {th }}$ of the current month, on the approval given by the Hungarian and Croatian legislative chambers to the draft law on the recognition of the Muslim cult. It seems necessary (ft is required) to present this Government with an appropriate and prudent protest. Therefore, I entreat Your Eminence to do this in the manner and in the form that will be most convenient. ${ }^{23}$
}

The tone of the first part is objective, being a simple acknowledgement of the situation. The use of the name: "culto musulmano", Muslim cult, is also more accurate than the previously seen predominant "Muhammadan" form. However, in the second part, the telling use of phrases indicates the objection to the developments: e.g. as first written: "occorre", 'it is required', which is then crossed out and refined to "sembra necessario", 'it seems necessary' to present an appropriate and prudent protest, "opportune e prudente protesta". The Holy See seeks to express its objections to the law Even after its entering into force. Gasparri only articulates his desire for such an objection to be voiced, but leaves the details to be figured out by the Pro-Nunzio who can judge what is most proper and con- 
venient under the given circumstances ("nel modo e nella forma che stimerà più conveniente").

The next letter, dated Zagrab, $25^{\text {th }}$ March 1916, and written by A. Bauer to the Apostolic Nuncio on the law, attests to the fact that the law, at the time of its sanctioning, attracted attention.

\footnotetext{
"It is my honor to transmit to your Most Revered Eminence the requested original text of the new law on the recognition of the Muhammadan cult as an attachment - with a Latin translation.

I [shall] not fail to remark again that with us, conversion from the Christian religion to a non-Christian cult is prohibited due to the indeletable character of the s. baptism, which is acknowledged by the law."24
}

The repeated usage of the form "Muhammadan cult" in contrast to "Christian religion" is seen to form a pattern. The act of sending the text of the law itself reflects genuine intetrest on behalf of the Nunciature, while the striving for accuracy in transmitting information is seen in the fact that alongside the original German text its Latin translation is also attached, ascertaining that the recipient should consult it in detail. The question of conversion is still central, but confirmation is given that from Christianity to non-Christianity it is legally impossible. The use of the word "transition" for leaving Christianity for a non-Christian religion or "cult" is noteworthy, and its usage referring to the outward direction in changing one's religious affiliation is also pattern-like, especially when contrasted to the use of the word "conversion" when an inward change is indicated.

Apart from contacting each other, members of the diplomacy of the Holy See also contacted politicians. One example of this is the letter written by Card. Scapinelli (Pro-Nuncio) to Card. Gasparri:.

\footnotetext{
"I have talked [to the] Foreign Minister on the law recognizing the Turkish religion in Hungary and Croatia.

According to him, these laws must be considered as directed to/aiming to regulate merely the civil status of the Muslim religion in the Monarchy.

I think it will certainly be sanctioned by the Emperor." ${ }^{25}$
}

This letter, written and sent shortly after the passing of the bill, further attests to the interest in the law, as well as to the gravity of the issue, given that the Foreign Minister is involved. Here we witness the intention to give a favourable and relieving interpretation to the law, namely that it is a mere administrative regulation. As for the use of lexicon, two expressions refer to Islam; and while one of them is seen to be accurate: religione musulmana, according Islam the status of a religion and using a derivative, Muslim, for the reference, the other, religione turca, is incorrect and anachronistic, being characteristic of the Late Middle Ages 
and Early Modernity, where 'Muslim' was interchangeable with 'Turk'. A possible justification for its occurrence might be the consideration of the legal acceptance of Islam as the religion practiced in Turkey.

Shortly after the previous letter, Card. Pro-Nuncio Scapinelli also went on to write to the Archbishop of Zagrab. In the upper right corner of this draft, a short comment written in pencil signals the primary concern of the letter, "Maometanisme Croatia".

"I give many thanks for the transmission of the text of the law concerning
the Muhammadan cult. I should be grateful if your eminency could
indicate if this law has received the sanction of His Majesty, or when it
should undergo such sanction.
In addition, I most politely ask Your Eminence about the following
question, namely, wether in the future the force of this law $(\S 3)$ may be
posed in the administrative norms so that the liberty of conversion from
Muhammadanism to the Catholic religion be permitted even [at/before]
the age of 18 years, especially in cases where both parents convert, or
agree that their sons who have not yet reached 18 years could convert."26

In less than a week, Card. Pro-Nuncio Scapinelli is seen responding to the Archbishop of Zagrab. His concise and specific letter shows that he had studied thoroughy the paragraphs of the text of the law sent by the Archbishop. Great interest is expressed in the date when sanction is expected. The central concern is the possible act of conversion from Islam to Catholicism, and speculation on possible arrangements that would be advantageous for the latter, facilitating the transition. The form cultum mahomedanum appears in this letter, too, as well as the form conversionis a mahomedanismo ac religionem catholicam, where Catholicism is a religion, and the direction of the change of affiliation is indicated by the word 'conversion'.

The letter written by the Hungarian Primate to Card. Scapinelli on $2^{\text {nd }}$ April 1916 is a response to a letter by the Cardinal written only a day or two before. The long and detailed answer demonstrates that the issue was still attracting attention, and provoked some worries, which, however, are sought to be dismissed in the following lines.

"Responding to the esteemed letters of Your Eminence that are dated the $1^{\text {st }}$ of the current month, I hurry to inform Your Eminence that the law regarding the acceptance of the Muhammadan cult has already been furnished with sanctioning by the court and is officially confirmed. On the other hand, with regard to conversions and receptions, the law mentioned above has not stated anything new compared to the above, but has extended the legal norms that had been in force so far concerning the conversions of all accepted confessions to Muhammadans. Given that the age when conversions are permitted is set in 18 years in our country, 
this norm will be in force also in case of Muhammadans. Children up to the age of seven follow the conversion of their parents; the change of religion in case of childern between 7 and 18 will be possible in cases where parents previously followed different religions and later go on to switch to the same confession. As to what concerns us most closely here and now, and as far as it can be foreseen, perhaps the entire law is or will be of no practical importance for a long time to come, and indeed its execution may not be commanded. For the Muhammadans first need to constitute religious communities, and how are they to form those if they have no followers of that cult? The entire legislation has the character rather of a political demonstration, but in practice it will have no effect, as we hope.

These regulations are or will be in force in Bosnia and Herzegovina, while in our country they cannot be brought into process; given, however, that Hungary has her own legislation, without whose cooperation nothing is possible in cases of this kind. This indeed finished the case of the law with its acceptence, to the point where without the new law nothing can be changed, and the govenrment, so to say, has asked for the law only under the coercing political circumstances and itself rejoices to have it passed without greater efforts and agitations. It is different in the case of Bosnia and Herzegovina, where, for these provinces, the govenment could have handled the matter without a law, through a mere governmental order it could coordinate and decree as it wanted, and conversions could be carried out at minor ages for those who are to convert. In our country, as I said, the norm is fixed at 18 years, we cannot hope for any change in this, nor can the revision of the whole ecclesiastical-political legislation be claimed, which is neither desirable nor possible now.

As for the practice, I still note the following. According to the law, Jewish children under the age of 18 can not be baptized, either, but actually, we frequently baptize them. The government, when informed on these [cases], may make inquires in single cases, but the end of the inquiry is that children remain baptized, and no one makes further inquiries with the passing of time. The same is likely to happen regarding Muhammadans. There will be loud voices/claims, but they will come to a halt, as water flowing in the arena usually vanishes." ${ }^{27}$

This letter at first attributes no practical importance to the law, but the reason it gives is not only the small number of adherents as much as the lack of an operational congregation - which accords well with the wording of the law. The law is explicitly considered to be of a political nature and to have been formulated due to coercing political circumstances. Subjective points of view are also voiced, such as the expression of "hope" (speramus) that the law would have no practical effect; or the "happiness" of the government to have it passed without "agitations" - i.e. without such reactions as might have been expected. A new approach introduced here is that the law does not impede existing practice: as it is seen in the case of the Jews who, according to the regulation, could also only be baptised 
after reaching the age of eighteen years, yet, the actual practice ignores this. Apart from the practice of the Church, we also learn about the official approach to such instances, namely that only in some cases does this ignoring of the regulation result in investigations, but even in those cases the loud claims die away quickly.

The letter written by the Archbishop of Zagrab, Antun Bauer, to the Apostolic Nuncio (Card. R. Scapinelli di Leguigno) on $7^{\text {th }}$ April 1916 is a quick response to the latter (who, as it is referred to and as we have seen above, had turned to him for information less than a week before):

\footnotetext{
"With reference to the most esteemed letters of your most revered Eminency from the $1^{\text {st }}$ April 1916, I reply the following:

The sanctioning of the law on the Muhammadan cult by His Sacred Majesty has not yet been made public law, thus I cannot respond to your most revered Eminency with any certainty whether it has taken place or not. New administrative norms cannot be formed around the conversion of Muhammadans, while it is definitely said that the law is produced through night work [i.e. by working day and night] by the government - in relation to other cults and churches, to give substance to the interconfessional law of $17^{\text {th }}$ January 1906.

So almost nothing can be known about this matter, and we must wait until the end of the war, maybe then there will be an occasion for a change for the better in the matter." ${ }^{28}$
}

The letter echoes some of the previously seen attitudes, i.e. the interest in the sanctioning of the law, as well as in the age of conversion. We also witness the approach that placed the recognition of Islam in the general context of the legal acceptance of religions; here, the earlier interconfessional law is also referred to. This way, the focus is widened: it is not only the status of Islam that matters, instead, the matter is viewed in the context of other similarly recognized religions. The necessity of possibe changes is also raised; however, it is indicated that only post-war circumstances may bring about such changes - a suggestion which may imply that the alliance with Turkey might require such a step.

Shortly after this, the Archbishop of Zagrab wrote another letter to the Nuncio, this time on Croatian "Muhammadanism" (to right corner: Croatia culte Musulmano), which attests to Scapinelli's having written a quick response to his previous missive (on $8^{\text {th }}$ April 1916), which is missing from the archives.

\footnotetext{
"To the questions expressed in the letter of your most revered Eminence of the $8^{\text {th }}$ April of the current year, I respond that the government's work of day and night on the law concerning the reception of the Cult of the Muhammadans has the prospect of authentic declaration. As for the transition to Muhammadanism, it is without doubt that such transition according to our laws should in no way be permitted, just as it is not in the case of Judaism". ${ }^{29}$
} 
The letter displays the familiar concern about the proclamation of the law, as well as the possibility of conversion - which, however, is not possible due to the legal regulation. As we have seen elsewhere, the status of Judaism often serves as an analogy to that intended for Islam.

The next available document dates to a month later, and was written by Ervin Roszner, "Le Ministre Royal Hongrois" to the Nuncio - on the accepted law. (In Scapinelli's hand, in the left corner: "ringraziato: il 16 maggio 16").

"I am urged to inform you that the law of the recognition of the Moham-
medan cult in Croatia has been sanctioned by His Majesty on $27^{\text {th }}$
April." ${ }^{30}$

Though the letter of the Nuncio is not available, the response demonstrates that the Nunziatures had also contacted politicians in order to gain insight into this significant event.

The next document ${ }^{31}$ is without a date or any specific comment, apart from a short note in pencil that reads "Per l'Austria". This piece of printed material (Ordinariats-Blatt der Budweiser Diöcese 1913 nr 9) contains the Austrian law of 1912 that had acknowledged the Hanafite rite. ("Gesetz vom 15. Juli 1912, betressend die Unertennung der Unhänger des Islams nach hanefitischen Ritus als Religionsgesellschaft") We may presume that the new law of 1916 also raised interest in earlier developments, i.e. that a study of the text of the previous law and its outcome (if any) was expected to help prognosticate what could be expected in the present instance.

After this, no other documents can be found until the following year, when the Secretary of State, Gasparri wrote to the Nuncio, Valfré di Bonzo (1916-19) as follows:

"In 1912, in Austria, as is certainly known to the Holy See [...], and later, in 1916, respectively, laws were passed in Hungary and Croatia to admit the Muslim cult in those countries. These laws are almost equal in substance and expressed in generic terms. Their practical determination cannot be expected until the first Muslim congregation is legally constituted in each of those countries. On that occasion the respective Minister of Culture will have the power to establish, through his Decrees, different points of practice, some of which may be important.

It is not known whether the establishment of any Muslim community has already taken place; but this could well happen, especially as both Vienna and Budapest intend to build a mosque. ${ }^{32}$ In view of all of this, it will be appropriate that Your Eminence be watchful so that, when the formation of a Muslim community occurs in the nominated countries, the practical application of the law should be carried out in order to bring the least possible damage to the prestige of the Catholic Religion and to the health of souls. 
Moreover, in Austria, the age at which, according to the already existing laws, the transition from one recognized religion to another is permitted is 14 years; in Hungary and Croatia it is 18 years. It is very probable that although this is not explicitly expressed in the admission laws of the Muslim cult, the same will be observed for the [case] of the passage from Musulmanism to Catholicism. Now, if by virtue of the powers granted by the aforesaid laws to the Minister of Culture we could obtain for this last case a lower age limit, this would be an advantage. In this regard it should be noted that, according to Muslim laws, the transition to another religion is accepted at the age of puberty, so that no injustice would be done to Muhammadanism.

Your Eminence will find in the Archives of this Nunciature a [...] position [posizione as an archival category] with regard to this question, whose documents may be useful for acquiring a fuller knowledge of the matter and thus taking the appropriate steps to the aforementioned purpose more effectively." ${ }^{33}$

A year having passed, the law is now seen in a broader perspective, contextualized in the passing of a series of similar bills. The practical side is investigated, particularly the issues in which the Church and politics may intervene, this is why the Holy See is seen to follow carefully the possible formation of any Muslim community. It is still considered a threat, as is indicated by prases such as "the least possible damage to the prestige of the Catholic Religion and to the health of souls" (il minor danno possibile al prestigio della Religione Cattolica ed alla salute delle anime). The age of conversion is still a concern, and there is still a mixed use of vocabulary, which sometimes uses the correct (Muslim, musulmano), in other cases the inaccurate (Muhammadanism, maomettanismo) form.

The last paragraph of the letter may explain the reason why the issue was raised. As there was a new Nuncio, Valfré di Bonzo, Secretary of State Card. Gasparri needed to draw his attention to the case and make sure that he should notice in time any relevant developments. In order to avoid the need to give an overview of the situation, he directs Valfré di Bonzo to the Archive where an entire fond is dedicated to the question.

The Nunzio replied six months later, indicating his subject as Culto mussulmano in Austria-Ungheria:

"In dispatch N. 27517 of March $8^{\text {th }}$ of the current year Your Most Revered Eminence called my attention to the admission of the Muslim cult in Austria-Hungary. I have not failed to deal with the matter immediately, especially by speaking to His Eminence the Cardinal Archbishop of Vienna who, precisely because of his ecclesiastical position, is interested in the matter more than anyone else.

He provided me only the other day, under the date of $13^{\text {th }}$ of the current month, with an answer which I transcribe ad litteram in adherence to 
your Eminence's norm, not without transmitting the text of the law of 9th August 1912, which concerns Muslim worship specifically.

"Moreover, Cardinal Gasparri, Secretary of State, in a letter sent to your Excellency on the date of $27^{\text {th }}$ March 1917, wrote about the acknowledgement of the Islamic religion in Austria - the law which I enclose here - so that he could take care of the matter on behalf of the bishops, and so that no harm should come to the Catholic Church at the time of its emergence. First of all, paragraph 6 should not be ignored, which provides equal protection to the teachings and institutions; even though it adds, "in so far as these are not contrary to the civil laws." - by which words [i.e. on the basis of such words] a benevolent government can obstruct the acknowledgement of such Muhammadan institutions as are contrary to Christian morality. Professor Dr. Schmöger has written at greater length on this law in the periodical "Salzburger Kirchenzeitung 1912 no. 48 and 49". The number of Muhammadans in Austria (except for Bosnia and Herzegovina) in 1909 was counted [somewhat] over 1281, of which more than 889 reside in Vienna."

For now, then, because of the war, there is no consideration or prospect for the construction of the mosque; but even after the war, especially given the good dispositions of His Majesty the Emperor, it will not be possible. I have drawn the attention of His Eminence the Cardinal Archbishop of Vienna, and, as for me, I will not fail to remain alert." ${ }^{34}$

The decreasing frequency of the correspondence illustrates that the issue came to a standstill. Even if some further discussions are referred to, no new developments are mentioned. The law is seen to be mostly a formality, and loopholes are pointed out that may provide ground for preventing further recognitions. Reference is repeatedly made to the circumstances of the war that definitely impede, for instance, the mosque building project. A letter from which the Nunzio quoted is attached, dated $13^{\text {th }}$ October 1917; it was written by the Archbishop of Vienna and addressed to Valfré di Bonzo. ${ }^{35}$

The answer, which is the last available document relevant to this matter is a confirmation of the arrival of the letter:

"I have duly received Report No. 2518, dated 21 October, concerning the Muslim Cult in Austria Hungary.

I have not failed to take notice of what you tell me in this Report, and I am sure that Your Eminence will continue to follow carefully this important topic and inform the Holy See should the occasion arise." ${ }^{36}$

The final voice in this documentation is then a request to remain watchful and to follow the latest happenings in the field. There are no further materials, which indicates that the issue lost its importance, and ceased to be an issue altogether after the end of the war. 


\section{Concluding remarks}

As a conclusion, first, the significance of the bill is underlined, then a brief reference is made to the circumstances and causes why it lost importance, and finally I would express my gratitude to those who have helped me in this research.

The significance of the bill is that it declares that Hungary has acknowledged Islam as a religion and not a denomination: it sought to secure that all Muslims should have the opportunity to form a denomination. Given that the bill did not aim at increasing the number of established religions, Islam was intended only to be legally recognized (in Hungarian: ,,elismert felekezet”, in Latin ,, licita religio"), i.e. the eventual congregation would not have had access to the privileges provided for the established religions, such as representation in legislation, easier access to estates, etc., but it would have been entitled to the same rights as other legally recognized religions, e.g. ensuring the religious education of children also by legal means; the right to collect denominational taxes, etc. The Act was never withdrawn, and the law has not been cancelled, but the Muslim legislation (ius personarum) had never became a part of the legal system of Hungary, and Islamic law never confronted the ius patrium. (Csiziné Schlosser 2010:253; Hamza 2016:22-23; Molodikova 2011:224; Szalai 2010:597-598.)

In WWI, however, Hungary was defeated, Bosnia thus became separated from the country, and the number of Muslims in the fragmented country decreased. The end of the war and the Treaty of Trianon had devastating effects on Hungary and on Muslims, as well. The result was a setback in the presence and religious practice of Muslims in Hungary. Uncertainties caused by the Treaty of Trianon and the outbreak of WWII finally led to a slow disappearance of the Islamic community. During the 1920s, the number of Muslims decreased by one third; the remaining community continued to live in the capital, but was mostly of different citizenship. Negative political and economical developments resulted in delaying the construction of the Budapest Mosque. (Lederer 1988:16; Molodikova 2011:224)

This research could not have been carried out without the support of Tibor Martí, who helped me in my preparation for the archive work, as well as of István Soós, who provided ideas for the formation of the scope of the examination. I am also grateful to Mons. Dr. Tamás Tóth who gave me advice concerning the fonds to be examined. Finally, I would like to express my gratitude to the staff of the Archives. 


\section{References}

Bolek Zoltán: Bosznia okkupálásától az iszlám törvényi elfogadásáig, avagy a modern kori iszlám története Magyarországon - In: Eds. Köbel, Szilvia; Tóth J. Zoltán: 100 éves a magyar iszlámtörvény (Budapest: KRE ÁJK, 2017) 38-58.

Csiziné Schlosser, Annamária: Az egyházak jogalanyiságának történelmi összefüggései - In: Iustum Aequum Salutare 6(2010)4:243-256

Hamza, Gábor, Jogtörténeti áttekintés a muszlimok magyarországi helyzetéröl - In: Pro futuro. A jövö nemzedékek joga 6(2016)2:11-23.

Köbel, Szilvia, Bevett nem keresztény felekezetek joga: Iszlám közösségek Magyarországon, Iszlám jog - In: Ed. Köbel, Szilvia: Az állami és a felekezeti egyházjog alapjai. (Budapest: Patrocinium, 2016) 489-499.

Krešić, Mirela, The matrimonial Law of the Muslims of Croatia 1916-41 - In: Eds. Beck Varela, Laura; Gutiérrez Vega, Pablo; Spinosa, Alberto: Crossing Legal Cultures (München: Martin Meidenbauer, 2009) 365-380.

Lederer, György: A magyarországi iszlám újabb kori történetéhez (I.) - In: Keletkutatás (1988)2:2949.

Molodikova, Irina: Formation of new Muslim communities in new member states: the case of Hungary - In: Ed. Katarzyna Gorak-Sosnowska: Muslims in Poland and Eastern Europe (Warsaw: University of Warsaw, 2011) 222-238.

N. Rózsa, Erzsébet: Muszlim kisebbségek Közép-Európában, avagy Közép-Európa különlegessége - In: Ed.: Rostoványi, Zsolt: Az iszlám Európában: Az európai muszlim közösségek differenciáltsága. (Budapest: Aula, 2010) 405-446.

Staničić, Frane: The Legal Status of Religous Communities in Croatian Law - In: Zbornik PFZ, 64(2014)2:225-254

Stipta István: Az iszlám vallás hazai elismeréséröl szóló 1916. évi XVII. tc. létrejötte és jogdogmatikai elemzése - In: Eds. Köbel, Szilvia; Tóth J. Zoltán: 100 éves a magyar iszlámtörvény 23-37.

Szalai, Miklós, Az 1916. évi VII. törvénycikk. Az iszlám vallás legalizálása Magyarországon - In: Történelmi Szemle 52(2010)4:593-601

\section{Notes}

1 The present article was prepared during a research stay in the Vatican Archives, in the framework of the Klebelsberg Kuno Grant (no. 749/KMIF/2017), provided by the Ministry of Foreign Affarirs and Trade (Hungary)

2 ISZLÁM 100. - ELTE BTK, 2016. 03. 30-31.; 100 éves a magyar iszlámtörvény 1916-2016 KRE ÁJK, 2016. 11. 22.;

3 All transaltions were provided by the author.

4 Some studies provide us with slightly different results, as e.g. Hamza 2016:23 states that it needs to be pointed out that according to the census taken in 1910 in the Kingdom of Hungary, including Croatia-Slovenia which enjoyed a large degree of autonomy, there were only as many as 757 citizens belonging to the Islamic religious community.

5 See also: Az iszlám jogállásának szabályozása Magyarországon, In the series A Magyar-Bosnyák-Herczegovinai Gazdasági Központ kiadványai, Budapest, 1913.

6 Letter, Raffaele Scapinelli di Leguigno to János Csernoch, 30th November 1915, original language: Latin. (Arch. Nunz. Vienna 766, fasc. 3; 46r) "Iam in ephemeridibus apparuit notitia de propositione novae legis a Camera legislatorum in Hungaria condendae super recognitione legali cultus mohamedani. 
Pono cum haec lex falsam sectam aequiparando in iuribus verae religioni, huic iniuriam inferat non levem certe a catholicis viris probari non potest; eo vel magis quod necessitas talis novae legis non appareat et aliunde per tollerantiam religiosam, ut(i) nunc viget in Hungaria, satis provisum socialibus necessitatibus sit.

Notendae autem veniunt inter alias hae consequentiae; quod recognita lege religione mohamedana, transitus admittatur ad hanc religionem e christiana inquod quo societate Christiana valde iniuriosum esset, et insuper eventualis conversio alicuius personae ex falsa religione mohamedana ad catholicam, subiecta erit restrictionibus et impedimentis quibus in Hungaria transitus de una ad aliam religionem, ex recognitis vinculatur.

Certe Eminentia Tuae curae erit ut si possibile fiat, haec lex non proponatur aut admovetur, vel saltem id eveniat cum minori danno et offensione catholicae religionis christianorum morum et libertatis quoad conversionem sensibus"

7 C.f. e.g. Stipta 2017:30.: The issue of the use of terminology was also present in the discussion of the law itself. For instance, an evaluator of the bill criticized the occurrence of the name „mohameddán vallás” (Muhammadan religion), referring to the rejection of such usage by the Prophet Muhammad himself. See also footnote 25.

8 C. f. Hamza 2016:20: Even after the occupation, in Bosnia-Herzegovina the sharia and the civil code, the mecelle, remained in force. Ahmad Gawdat (1822-1895) pasha published the mecelle between 1869 -1876 in 16 volumes, having received in 1846 a request on behalf of the great vizier Mustafa Reshid for the codification-compilation with the aim of the Europeanization of the civil code of the Ottoman empire. This compilation follows mostly the Hanafi rite, is based on the sharia and formally, i.e. in its structure, follows the codex model of central and western Europe. The mecelle was applied to non-muslim subjects, as well.

9 The correct form is balig (its etymology coming from the Arabic language), which means pubescent, or, more literally [someone] reaching [maturity].

10 Letter, Raffaele Scapinelli de Leguigno to Card. János Csernoch, 8/December/1915, original language: Latin (Arch. Nunz. Vienna 766, fasc. $345 r$-v) "Veneratissimas letteras accepi Eminantiae tuae reverendissimae ex quibus novi gubernium hungaricum moveri non posse ad retractandam propositionem legis de receptione mahumedani cultus. Quod valde dolendum est propter dedecus christianae legislationis ex motivis politicis inflictum.

Spes fovenda est ut apostasiae christianorum non eveniant; sed curandum est ex altera parte ut libertas conversionis ex mahumetanismo ad catholicam religionem, per novam legem non minuatur, sive per difficultates et formalitas burocraticas, sive quoad aetatem praescriptum, etc. In Austria aetas 14 annorum, in Hungaria et Croatia 18 annorum uti minimum requisitur in convertendo. In Turchia tantum aetas pubertatis in convertendo requisitur, et iuxta „medzelle” pueri inter 12-15 annos, puellae vero inter 9-15 puberes (baliq) considerantur. Ideoque poterit, absque iniuria pro Turcis, iam ab hac aetate liberas conversionis admittis, etiam a lege Hungarica.

Statuere aetatem pro conversione est semper iniusta limitatio libertatis, a iure naturali manantis, amplectendi veram religionem statim ac homo hanc uti talem cognoscat etiam in tenera aetate; sed curandum est ut haec limitatio ad minimum reducatur.

Confidaliter autem E. T. dicere possum quod in propositione novae legis quae pro Bosniae et Herzegovina paratur, iuxta praedicta criteria aetas minima pro conversione in 15 annos * stabilitur, et pro muliere uxorata etiam ante hanc aetatem conversio permittitur. Usque formalitate burocraticae simplificantur.

Si aliquid circa haec in bonum religionis fieri possit certe E.V. hoc curabit

*quae forsan etiam ad 14 reduci poterit sicut in Austria"

11 Printed material (Arch. Nunz. Vienna 766, fasc. $340 r-v$ ) "Die islamitische Religion wird als eine gesetzlich anerkannte Religion erklärt" The Islamitic religion is declared as a legally recognized religion" 
12 "§ 1. Die islamitische Religion wird als eine gesetzlich anerkannte Religion erklärt $\S 2$. Zur Konstituierung einer Konfessions-Gemeinde von Anhängern der mohammedanischen Religion ist es nicht notwendig, die auf die Dogmen und die ethischen Lehren, den Gottesdienst und die sonstigen religiösen Zeremonien Bezug habenden Vorschriften zu präsentieren und werden dieselben bei der Genehmigung der Organisations-Statuten, welche auch alle übrigen auf das Glaubensleben bezüglichen Bestimmungen enthalten, einer Prüfung nicht unterzogen. $\S 3$. Die Organisation der mohammedanischen Konfession in Ungarn Kann mit Genehmigung für Kultus- und Unterricht mit der in Bosnien und in der Herzegovina bestehenden gesetzlichen Organisation der Anhänger des Islams in Verbindung gebracht werden.

Priester und Gemeinde-Vorstand oder Mitglied der höheren Gemeindeorganisationsvertretung kann mit Genehmigung des Ministers für Kultus und Unterricht auch ein solches Mitglied der Konfessions-Gemeinde sein, dessen Befähigung entspricht, auch können Priester schon vor der Konstituierung der ersten Konfessions-Gemeinde angestellt werden, wenn ihnen ein eihrer Stellung entsprechendes Einkommen gesichert wird.

$\S 4$. Die Ausübung der islamitischen Religion, sowie dessen Glaubensgrundsätzen, Lehren und Istitutionen geniessen, in Ramen der Bestehenden Gesetze, den den gesetzlich anerkannten Religionen gebrührenden Rechtschutz.

Im Übrigen sind für die mohammedanische Religion die für die gesetzlich anerkannten Konfessionen giltigen Rechtbestimmungen massgebend. Die eventuell notwendigen weiteren Abweichungenwerden vom Ministerium im Verordnungswege festgestellt werden.

$\S 5$. Dieses Gesetz tritt am Tage der Publizierung in Kraft und wird vom Minister für Kultusund Unterricht, dem Minister des Inneren und dem Justizminister durchgeführt."

13 Note (Arch. Nunz. Vienna 766, fasc. 341 r-v): "Progetto di legge riguardante il riconoscimento della religione islamitica

Il progetto porta il $\mathrm{Nr} 1219$ e la data 30 Novembre 1915

$\S 1$. La religione islamitica si dichiara religione legalmente riconosciuta.

L'esercizio della religione islamitica, la sua dottrina e le sue istituzioni in quanto non sono contrari alle leggi godono di quella tutela legale che tocca alle religioni legalmente riconosciute,

§2. Le norme riguardanti la dottrina, il culto e altre cerimonie religiose - quando si tratterà della formazione della società religiosa islamitica non dovranno essere né esibite/presentate/ né esaminate.

§3. L'organizzazione della società religiosa islamitica /Religiongesellschaft/, con permesso del ministro del culto e della pubblica [...unreadable...] coll' organizzazione della religiosa società islamitica già esistente in Bosnia-Erzegovina [...unreadable...] ministri religiosi potranno essere adibiti anche que che sono stati qualificati in Bosnia Erzegovina. Tali ministri religiosi potranno essere adibiti anche [...unreadable...] che qualche communità culturale.

$\S 4$. Per altro per la società religiosa constituiscono la direttiva quelle leggi e regole di diritto, che riguardano altre società religiose riconosciute. Le divergenze eventuali saranno fissate dal ministro del culto e della pubblica istruzione."

$\S 5$. Questa legge entra in vigore il giorno della promulgazione. L'esecuzione della legge appartiene al ministro del culto e della pubblica istruzione.

14 Note (Arch. Nunz. Vienna 766, fasc. 342 ) ' "L'exercise de la religion islamique ainsi que ses dogmes, ses articles de foi et ses institutions jouissent dans le cadre des lois en vigueur de la protection légale due aux religions légalement reconnues.

$\mathrm{Au}$ reste servent de règle pour la religion mahomètane les normes légales valable pour les confessions légalement reconnues, Les exceptions éventuellement nécessaires seront détermines en voie d'ordonnance par le ministére. (1895. 45.)"

15 Original text in Hungarian: “Az iszlám-vallás törvényesen elismert vallásnak nyilváníttatik". 
16 Original text in Hungarian: “A mohamedán vallást követők vallásfelekezetté alakulásához a hitelvi, az erkölcsi tanokra, az istentiszteletre és egyéb vallási szertartásra vonatkozó szabályok bemutatása nem szükséges és azok a hitéletre vonatkozó összes többi rendelkezéseket magában foglaló szervezeti szabályzat jóváhagyásakor nem esnek vizsgálat alá"

17 Original text in Hungarian: “A mohamedán vallásfelekezet magyarországi szervezete, a vallásés közoktatásügyi miniszter jóváhagyásával, összefüggésbe hozható a mohamedán vallást követőknek Boszniában és Hercegovinában fennálló törvényes szervezetével. Lelkész és egyházközségi elöljáró, vagy a felsőbb egyházszervezeti képviselet tagja, a vallás- és közoktatásügyi miniszter jóváhagyásával, a felekezetnek oly tagja is lehet, akinek képesítése a Boszniában és Hercegovinában ily állásra megkívánt képesítésnek felel meg, ugyanígy lelkészek már az első hitközség megalakulása elött is alkalmazhatók, ha számukra állásukhoz mért megélhetés biztosíttatik."

18 Original text in Hungarian: "Az iszlám-vallás gyakorlása, valamint hitelvei, tanai és intézményei a fennálló törvények korlátain belül a törvényesen elismert vallást megillető jogvédelemben részesülnek. A mohamedán vallásfelekezetre egyebekben a törvényesen elismert vallásfelekezetekre vonatkozó jogszabályok irányadók. Az esetleg szükséges további eltéréseket a minisztérium rendelettel állapítja meg."

19 Original text in Hungarian: "ez a törvény a kihirdetés napján lép életbe s azt a vallás- és közoktatásügyi miniszter, a belügyminiszter és az igazságügyminiszter hajtja végre."

20 „Il 6 marzo 1916 fu scritto all'arciv. di Zagrabia, nello stesso senso delle due lettere al Card. Czernoch 30. nov. e 8. dec. 1915"

21 Letter, Archbishop Antun Bauer to Card. Raffaele Scapinelli di Leguingno, 9/March/1916. Original language: Latin (Arch. Nunz. Vienna 766, fasc. 3 50r)

"Confidentiales litteras Eminentiae Tuae Reverendissimae de 6 martii a. 1. [anno labente] me rite recepisse hisce testor.

Lex tamen, de qua in litteris agitur, jam in Camera legislatorum pertractata et recepta est. In eadem vero lege nullibi sermo est, de cultus mahomedani aequiparatione cum religione christiana ac in specie catholica, nec permittitur transitus a religione christiana ad cultum mahomedanum. Per novam legem volebant de cultu mahomedano quae hucusque volebant de religione judaica, ad quam christianis non est fas transire.

Scio se quidam non adesse sufficientes rationes pro hac lege condanda, cum pauci tantum (200 et aliquot super) mahomedani in Croatiae regno existant; sed quum sic. [?],qualis lex in Hungaria ob politicas rationes condita nuper sit, nihil profecissem apud Gubernium et Cameram contra agendo. Ideo tantum passive restiti, idemque sacerdotibus suadebam, qui membra sunt camerae. De mutatione autem legis interconfessionalis in praesentibus rerum circumstantiis nihil fieri potest.

Sensibus .... reverentiae in osculo sacrae purpurae permaneo"

22 Letter, Card. Raffaele Scapinelli to the See of Rome, date of arrival: 17/March/1916. Original language: Italian (Aff Ecl. Fasc. 466 51r)

"Camere legislative Ungherese e Croazia hanno approvato progetto legge riconoscimento culto Musulmano, gia vigente in Bosnia-Erzegovina e Austria. Avendo a suo tempo richiamata attenzione Cardinale Primate ed Arcivescovo Zagrabia su tale progetto, mi risposero essere impossibile impedire approvazione voluta motivi politici: del resto conseguenze pratiche essere quasi nulle, sia per esiguo numero Musulmani in questi paesi, sia per limitati diritti inerenti a questo riconoscimento."

23 Letter, Card. Pietro Gasparri to Raffaele Scapinelli, cit. (Aff Ecl. Fasc. 466 52r)

"Ricevuto suo cifrato 16 corrente relativo approvazione data dalle Camere legislative ungherese e croata al progetto di legge sul riconoscimento del culto musulmano. Sembra necessario 
(Oeeorre) presentare codesto Governo opportuna e prudente protesta. Prego quindi Vostra Eminenza di farla nel modo e nella forma che stimerà piu conveniente."

24 Letter, Card. Antun Bauer to Card. Raffaele Scapinelli di Leguigno, 25/March/1916. Original language: Latin (Arch. Nunz. Vienna 766, fasc. 3, 51 r.)

"Honori mihi duco Eminentiae Tuae Reverendissimae in advoluto transmittere expetitum textum originalem novae legis de receptione cultus mohamedani una cum versione latina.

Iterum animadvertere non omitto, apud nos transitum ex religione christiana ad cultum non christianum, ob indelebilem characterem s. baptismi a lege agnitum vetitum esse."

25 Letter, Card. Raffaele Scapinelli di Leguigno to Card. Pietro Gasparri, date (of arrival) 30/ March/1916, original language: Italian (Segr St. anno 1916 rubr 247 fasc 1 105r)

"Ho parlato Ministro Esteri sulla legge riconoscente la religione turca in Ungheria e Croazia.

Tali leggi, secondo lui, debbono considerarsi come solo dirette a regolare situazione civile religiosa musulmana nella Monarchia.

Credo che sarà senz'altro sanzionata dall'imperatore"

26 Letter, Card. Raffaele Scapinelli di Leguigno to Archbishop Antun Bauer, 1/April/1916. Original language: Latin (Arch. Nunz. Vien. 766. f3. 60r)

"Gratias quamplurimas ago de transmissione textus legis circa cultum mahomedanum. Gratum autem mihi erit si E. V. mihi significaret an lex ipsa jam sanctionem suae maiestatis acceperit, vel quando huic sanctioni subjicitur.

Insuper de questione sequente ab P. Tuae humanissime peto: scilicet an in posterum, vi legis ipsius (§3) normae administrativae statui possunt ad hoc ut libertas conversionis a mahomedanismo ac religionem catholicam admittatur etiam ante XVIII annum aetatis speciatim vero in casu quo parentes ambo convertantur, aut consentiant filios suos converti posse 18 annum nondum agentes."

27 Letter, János Csernoch to Card. Raffaele Scapinelli di Leguigno, 2/April/1916, original language: Latin (Arc. Nunz. Vien. $766 f 343 r$-v-44r)

"Respondendo aestimatissimis litteris Eminentiae Vestrae ddto [sic!] 1. curr. festino Eminentiam Vestram certiorem reddere legem de receptione cultus Mohamedani sanctione regia jam provisam et officiose publicatam esse. Quod vero ad conversiones et receptiones attinet, desuper lex nihil novi statuit, sed legales normas quoad conversiones omnium hucusques receptarum confessionum vigentes, ad Mohamedanos quoque extendit. Quum vero aetas in qua conversiones licitae sunt, apud nos in annis 18 praescripta sit, norma haec quoad Mohamedanos quoque valebit. Proles usque ad annum aetatis septimum religionem parentum conversorum sequuntur. Mutatio religionis prolium inter annum 7. et 18. tunc tantum est possibilis, si parentes prius diversae religionis, posterius ejusdem confessionis fiunt. In proximo pro hic et nunc, et prout praevideri potest, longo adhuc tempore tota quanta lex apud nos nullius est, vel erit practici momenti et fors nec executioni mandabitur. Prius enim Mohamedani apud nos societates religiosas debent constituere, ast quomodo illas constituent, quum nullos apud nos sui cultus asseclas habeant? Tota quanta legislatio characterem potius demonstrationis politicae habet, ast in praxi nullos habebit, prout speramus effectus.

Quae hoc in negotio in Bosnia et Hercegovina fiunt vel fient, apud nos in exemplum adduci nequeunt; siquidem Hungaria propriam habet legislationem, absque cujus cooperatione in similibus negotiis nihil fieri potest. Haec vero jam cum acceptatione legis causam terminavit adeo, ut absque nova lege nihil immutari possit, Gubernium sub coactione, ut ita dicam, circumstantiarum politicarum duntaxat rogavit legem et ipsum gaudet, quod causam hanc absque majoribus moliminibus et agitationibus superatam habeat. Aliter se habet res in Bosnia et Hercegovina, ubi constitutum pro his provinciis Gubernium rem absque lege, via duntaxat ordinum gubernalium coordinare potest statuereque, ut conversiones etiam in minori convertendorum aetate fieri queant. Apud nos, prout dixi, norma in 18 annis statuta est, circa quam nullam mutationem, 
nunc saltem, sperare possumus, hoc enim revisionem totius legislationis ecclesiastico-politicae deposceret, quae nunc nec optabilis, nec possibilis est.

Quoad praxim sequentia adhuc adnoto. Juxta legem nec Judaeorum proles ante annum 18 baptizare liceret; nos tamen passim baptizamus illas. Gubernium, quando queralae ad ipsum deferuntur, in singulo caso inquirere solet, sed finis inquisitionis est, quod proles baptizatae remaneant et decursu temporis nemo illas amplius inquietet. Ita erit verosimiliter etiam cum Mohamedanis. Fient clamores, sed illi contiescent, prout aqua in arena discurrens evanescere solet."

28 Letter, Antun Bauer to Card. Raffaele Scapinelli di Leguigno, 7/April/1916, original language: Latin (Arch. Nunz. Vien. $766 f 3$ 61.)

"In nexu ad aestimatissimas literas Eminentiae Vestrae Reverendissimae de die 1. Aprilis 1916. respondeo sequentia:

Legis circa cultum Mahometanum per Suam Sacratissimam Majestatem secuta sanctio nondum est publici juris facta, ideoque utrum jam secuta sit nec ne, non possum Eminentiam Vestram Reverendissimam certiorem reddere. Administrativae normae circa conversionem Mahometanorum novae statui non possunt, cum in lucubratione a Gubernio legi addita expresse dicatur in relatione ad alios cultus et ecclesias valorem habere legem inter confessionalem de die 17. Januarii 1906.

De hac ergo re modo nihil fieri potest et expectandum est usque ad finem belli; fors tunc occasio erit, ut res in melius mutetur.

Dignetur Eminentia Vestra Reverendissima interim sensus venerationis meae profundissimae accipere, in qua permaneo in osculo Purpureae Sacrae servus in Christo addictissimus"

29 Letter, Antun Bauer to Card. Raffaele Scapinelli di Leguigno, 11/April/1916, Original language: Latin (Arch. Nunz. Vien. $766 f 363 r$ )

"Ad quaestiones, literis Eminentiae Tuae Reverendissimae de die 8. Aprilis a. 1. expressas, respondeo, lucubrationem a Gubernio legi de receptione cultus Mahometani additam habere rationem authenticae declarationis. Quod vero transitum ad Mahometanismum attinet, dubio omnio caret, talem transitum secundum leges nostras nullo modo esse permissum sicut nec as Judaismum."

30 Letter, Ervin Roszner to Raffaele Scapinelli di Leguigno, 16/ May/1916 (Arch. Nunz. Vien. 766. f3 64.)

„Votre Éminence,

En réponse de votre très honorée j'ai hâte de vous faire part que la loi de reconnaissance du culte mahométan en Croatie a été sanctionnée par Sa Majesté le 27 avril."

31 Printed material Arch Nunz. Vien. 766. f3 66.

32 C.f. Szalai 2010:596. The idea of the construction of a mosque was presented by Rezsö Havass at the Town Hall in December 1914, emphasizing that the capital owes this to the Bosnian soldiers of the Monarchy, but, on the other hand, a gesture like that would win the sympathy of the Islamic world for Hungarian interests - that would be important both from the approach of foreign policy and commerce. The proposal was accepted by the Council of the Capital on $4^{\text {th }}$ April 1916. As a consequence, a Mosque-Building Committee was formulated under the leadership of Zsigmond Perényi.

33 Letter, Card. Pietro Gasparri to Valfré di Bonzo, 08/March/1917. Original language: Italian (Arch. Nunz. Vien. 806 Fasc. $6422 r$-v - it is the actually sent typewritten version; but the hadwritten draft version is preserved, as well: Segr. Stato, Rapporti con gli stati, Affari Eccl. Periodo iii. Austria-Ungheria Fasc. 494 59r-60v; yet another handwritten draft version can be found under Segr. Stato,Rapporti con gli stati, Affari Eccl. Periodo iii. Austria-Ungheria Fasc 49461 r-v, 62.) Illmo e Revmo Signore

Nel 1912 in Austria, com'è certamente noto alla S. V. Illma e Revma, e più tardi, nel 1916, in Ungheria ed in Croazia furono rispettivamente approvate leggi portanti l'ammissione del culto 
musulmano in quei paesi. Tali leggi sono pressochè eguali nella sostanza ed espresse in termini generici. Una determinazione pratica di esse si farà soltanto, come nelle medesime viene stabilito, quando in ciascheduno di quei paesi si costituirà legalmente la prima Comunità religiosa musulmana. In tale occasione il rispettivo Ministro dei Culti avrà facoltà di stabilire, con suo Decreto, diversi punti di pratica, alcuni dei quali potranno essere importanti.

Non consta che sia già avvenuta la costituzione di qualche Comunità musulmana; ma ciò potrebbe ben avvenire, tanto più che sia a Vienna come a Budapest si progetta l'erezione di una moschea. In vista di tutto ciò sarà opportuno che la S.V. vigili affinchè, avvenendo qualche costituzione di Comunità musulmana nei detti paesi, l'applicazione pratica della legge venga fatta in modo da portare il minor danno possibile al prestigio della Religione Cattolica ed alla salute delle anime.

Inoltre, in Austria l'età in cui, secondo le leggi già esistenti, è permesso il passaggio da una religione riconosciuta ad un'altra è di 14 anni; in Ungheria ed in Croazia è di 18 anni. É molto probabile che sebbene ciò non sia esplicitamente espresso nelle leggi di ammissione del culto musulmano, altrettanto sarà osservato pel caso di passaggio dal musulmanesimo al cattolicismo. Ora, se in forza dei poteri concessi dalle predette leggi al Ministro del Culto si potesse ottenere per questo ultimo caso un limite minore di età, ciò sarebbe un vantaggio. Al qual proposito è da notare che, secondo le leggi musulmane, il passaggio ad un'altra religione è ammesso all'età della pubertà, di guisa che nessuna ingiuria verrebbe fatta al maomettanismo.

La S. V. troverà nell'Archivio di cotesta Nunziatura una intiera posizione in riguardo a tale questione, dei cui documenti potrà utilmente valersi per acquistare una più piena conoscenza della questione e fare così più efficacemente i passi opportuni al suindicato scopo; io, intanto, con sensi di ben distinta e sincera stima passo al piacere di rafferarmi di V. S. Illma e Revma Servitore, Gasparri (Quest. Rel).

34 Letter, Valfré di Bonzo to Card. Pietro Gasparri, 21/October/1917, original language: Italian/ Latin (two versions, in a handwritten, draft one, Arch. Nunz. Vien. $806 \mathrm{f6} 423 \mathrm{r}$ and in a typewritten one Arch. Nunz. Vien. $806 f 6424 r-v$ - another version can still be found in: Aff. Eccl. Periodo iii. Austria-Ungheria, anno 1914-1917, pos. 1204-1206, fasc. 494. 63).

„Con Dispaccio N. 27517 dell'8 Marzo u. s. l'Eminenza Vostra Reverendissima richiamava la mia attenzione sull'ammissione del culto mussulmano in Austria-Ungheria. Io non ho mancato di occuparmi subito della cosa, soppratutto parlandone con Sua Eminenza Revma il Cardinale Arcivescovo di Vienna, che appunto per la sua posizione ecclesiastica è più che ogni altro interessato nella questione.

L'Eminentissimo Cardinale Arcivescovo soltanto l'altro giorno mi ha fatto tenere, sotto la data del 13 corr, una risposta che trascrivo ad litteram per norma di vostra Eminenza, non senza trasmettere il testo della legge 9 Agosto 1912, che riguarda appunto detto culto mussulmano.

„Quod porro Emmus ac Revmus Dnus Cardinalis Gasparri, Secretarius Status Sanctitatis Suae, in Litteris ad Excellentiam Vestram Revam missis dd 27. III. 1917 N. 27517 scripsit de agnitione religionis Islamisticae in Austria - quam legem hisce accludo - revera ita se habet et cautio ab Episcopis adhibenda erit, ne Ecclesia Catholica constitutionibus suo tempore condendis detrimentum capiat. Praeprimis non negligendus est paragraphus 6, qui doctrinis, institutionibus et consuetudinibus Mahummedanis eandem tuitionem praebet sicuti ceteris Confessionibus; at vero adjungit ,,in quantum legibus civilibus non repugnant.” Quibus ex verbis benevolum gubernium agnitionem institutionum Muhammadarum, quae moralitati christhianae sunt contraria, impedire posset. Fusius de hac lege Professor Dr. Schmöger in folio periodico „Salzburger Kirchenzeitung 1912 Nr. 48 et 49” scripsit. Muhammedanorum numerus in Austria (exceptis Bosnia et Herzegovina) anno 1909 censebatur supra 1281, quorum Viennae supra 889 habitant." 
Per ora poi stante la guerra, non si ha alcun pensiero né progetto di erezione di Moschea; ma neppure dopo la guerra, date specialmente le buone disposizioni di Sua Maestá l'Imperatore, sarà possibile la cosa. A buon conto ho richiamato l'attenzione di Sua Eminenza il Cardinale Arcivescovo di Vienna, e per parte mia non mancherò di vigilare."

35 Original language: Latin (Arch. Nunz. Vien. 806 Fasc.6 $425 r$-v) Given that this argument is not related to the present investigation, it is not transcribed here in its entirety - the piece cited was integrated in the previous document.

36 Letter, Gasparri to Valfré di Bonzo, 10/November/1917, original language: Italian (Arch. Nunz. Vien. 806 Fasc. 6426 r).

"Ho regolarmente ricevuto il Rapporto N. 2518, de 21 Ottobre scorso, riguardante il Culto Mussulmano nell'Austria Ungheria.

Non ho mancato di prendere conoscenza di quanto ella mi comunica in detto Rapporto e son certo che V. S. continuerà a seguire con attenzione tale importante argomento per riferirne, eventualmente alla S. Sede."

Open Access. This is an open-access article distributed under the terms of the Creative Commons Attribution 4.0 International License (https://creativecommons.org/licenses/by/4.0), which permits unrestricted use, distribution, and reproduction in any medium, provided the original author and source are credited, a link to the CC License is provided, and changes - if any - are indicated. (SID_1) 
